\title{
Analisis Penggunaan Metode Eksperimen Pada Pembelajaran Sains Bagi Anak Usia Dini
}

\author{
Fajar Farham Hikam ${ }^{1}$, Erwin Nursari ${ }^{2}$ \\ 1,2 Pendidikan Islam Anak Usia Dini, STIT NU Al-Farabi \\ e-mail : farhan.hikam@gmail.com ${ }^{1}$, erwinnursari01@gmail.com²
}

\begin{abstract}
ABSTRAK. Penelitian ini bertujuan untuk mendeskripsikan atau menggambarkan secara objektif bagaimana penggunaan metode eksperimen pada pembelajaran sains bagi anak usia dini di RA Nurul Hidayah Desa Harumandala Kecamatan Cigugur Kabupaten Pangandaran. Jenis penelitian yang digunakan adalah penelitian lapangan yang bersifat deskriptif. Teknik pengumpulan data yang digunakan antara lain teknik observasi, wawancara, dan teknik dokumentasi. Sedangkan untuk menganalisis data yang diperoleh, penulis lakukan dengan cara mengumpulkan seluruh data, mereduksi data, menyajikan data dan verifikasi data. Hasil penelitian menunjukan bahwa penggunaan metode eksperimen pada pembelajaran sains di RA Nurul Hidayah Desa Harumandala Kecamatan Cigugur Kabupaten Pangandaran dapat meningkatkan kemampuan anak dalam memahami konsep sains sederhana dan meningkatkan motivasi anak terhadap pembelajaran sains di RA Nurul Hidayah Harumandala dan hasilnya sebagian besar anak dalam kategori berkembang sangat baik.
\end{abstract}

Kata Kunci : Anak Usia Dini, Metode Eksperimen, Pembelajaran Sains.

ABSTRACT. This study aims to: describe objectively how to use experimental methods in science learning for early childhood in RA Nurul Hidayah Harumandala Village Cigugur District Pangandaran Regency. The type of research used is descriptive field research. Data collection techniques used include of observation, interview, and documentation techniques. Meanwhile, to analyze the data obtained, the writer did it by collecting all the data, reducing the data, presenting the data and verifying the data. The results showed that the use of the experimental method in learning science at RA Nurul Hidayah Harumandala Village Cigugur District Pangandaran Regency can improve children's abilities in understanding simple science concepts and increase children's motivation towards learning science at RA Nurul Hidayah Harumandala and the result is that most children are in the very well developed category.

Keyword : Early Childhood, Experimental Method, science learning 


\section{PENDAHULUAN}

Dalam Undang-Undang RI nomor 20 tahun 2003 tentang Sistem Pendidikan Nasional Bab 1 Ayat 14 dijelaskan bahwa pendidikan anak usia dini adalah suatu upaya pembinaan yang ditunjukan kepada anak sejak lahir sampai usia 6 tahun yang dilakukan melalui pemberian rangsangan pendidikan untuk membantu pertumbuhan dan perkembangan jasmani dan rohani agar anak memiliki kesiapan dalam memasuki pendidikan lebih lanjut, baik pendidikan secara formal di sekolah maupun secara nonformal[1]. Menurut Yuliani Anak merupakan manusia kecil yang memiliki potensi yang masih harus dikembangkan. Anak memiliki karakteristik tertentu yang khas dan tidak sama dengan orang dewasa, mereka selalu aktif, dinamis, antusias dan ingin tahu terhadap apa yang dilihat, didengar, dirasakan, mereka seolah-olah tak pernah berhenti bereksplorasi dan belajar[2]. Anak usia dini adalah individu yang sedang mengalami proses pertumbuhan dan perkembangan yang sangat pesat, bahkan dikatakan sebagai lompatan perkembangan. Anak usia dini memiliki rentang usia yang sangat berharga dibanding usia-usia selanjutnya karena perkembangan kecerdasannya sangat luar biasa. Usia tersebut merupakan fase kehidupan yang unik, dan berada pada masa proses perubahan berupa pertumbuhan, perkembangan, pematangan dan penyempurnaan, baik pada aspek jasmani maupun rohaninya yang berlangsung seumur hidup, bertahap, dan berkesinambungan[3].

Pendidikan selalu berkenaan dengan upaya pembinaan manusia, oleh sebab itu keberhasilan pendidikan sangat bergantung pada unsur manusianya yang menjadi penentu akan berhasil atau tidaknya sebuah pendidikan. Menurut Musfiroh Pendidikan Anak Usia Dini merupakan pendidikan yang diselenggarakan untuk mengembangkan keterampilan yang merupakan pendidikan dasar serta mengembangkan diri secara utuh sesuai dengan asas pendidikan sedini mungkin dan sepanjang hayat. Aspek yang dikembangkan dalam pendidikan anak usia dini adalah aspek pengembangan pembiasaan meliputi sosial, emosi, kemandirian, moral, dan nilai-nilai agama, serta pengembangan kemampuan dasar yang meliputi pengembangan bahasa, kognitif, dan fisik motorik[4]. Sekolah adalah pihak kedua yang terkait dalam urusan pendidikan, dan tidak kurang penting dari rumah maupun masyarakat. Bahkan dengan perbedaan waktu tempat serta faktor-faktor lain, peran sekolah dapat melampaui peranan rumah dan masyarakat. Sekolah melaksanakan tugas pendidikan, yakni merealisasikan tujuan yang ingin dicapai dan berperan serta dalam memikul tanggung jawab umum dalam mempersiapkan anak yang saleh dan membangun generasi yang lebih maju[1]. Pendidikan bagi anak usia dini sangat penting, karena dalam pendidikan tersebut merupakan dasar bagi pembentukan kepribadian manusia, sebagai peletak dasar budi pekerti luhur, kepandaian dan keterampilan. Selama tahun pertama otak bayi berkembang sangat pesat dimana menghasilkan bertriliun-triliun sambungan antar sel. Sambungan antar sel akan semakin kuat apabila diberikan stimulasi atau rangsangan dan semakin sering digunakan. Namun sebaliknya akan melemah bahkan musnah apabila tidak pernah digunakan dalam proses kognitif. Hasil penelitian menyebutkan apabila anak jarang disentuh, jarang diberikan rangsangan baik visual, verbal maupun taktil dan kinestik maka perkembangan otaknya 20\% sampai $30 \%$ lebih kecil dari ukuran normal anak usianya[5].

Demi mewujudkan pendidikan anak usia dini yang baik harus didukung dengan adanya sumber daya manusia yang memadai. Dengan kata lain, guru yang merupakan pembimbing dan teladan bagi anak-anak wajib mempunyai kecakapan yang baik dalam kegiatan pembelajaran. Yaitu bagaimana seorang guru bisa mengajar dengan penuh kegembiraan dan keceriaan dihadapan peserta didik, serta dapat mengelola 
pembelajaran yang aktif, kreatif, dan menyenangkan. Dengan sumber daya manusia yang baik, kegiatan pembelajaran akan berlangsung dengan mengasyikan dan menyenangkan sehingga peserta didik tidak akan merasa jenuh dan bosan dalam mengikuti pembelajaran[6]. Rentang usia anak usia dini yaitu 0-6 tahun dan sering disebut dengan masa keemasan (the golden age). Pada masa tersebut sangat menentukan untuk masa-masa selanjutnya. Keberhasilan akan pertumbuhan dan perkembangan pada masa ini juga akan berpengaruh pada keberhasilan masa-masa setelahnya. Untuk itu, pendidikan anak usia dini memegang peranan penting dalam pertumbuhan dan perkembangan.

Anak usia dini memiliki karakteristik yang khas baik secara fisik dan mental. Oleh karena itu, strategi dan metode pembelajaran yang diterapkan pada anak usia dini perlu diterapkan oleh seorang guru sangat berpengaruh terhadap keberhasilan proses pengajaran. Penggunaan metode pengajaran yang tepat dan sesuai dengan karakter anak, akan dapat memfasilitasi perkembangan berbagai potensi dan kemampuan anak secara optimal serta tumbuhnya sikap dan perilaku yang positif pada anak[7]. Pembelajaran pada anak usia dini pada hakikatnya adalah pengembangan kurikulum secara konkret berupa seperangkat rencana yang berisi sejumlah pengalaman belajar melalui bermain yang diberikan kepada anak usia dini berdasarkan potensi dan tugas perkembangan yang harus dikuasainya dalam rangka pencapaian kompetensi yang harus dimiliki oleh anak[8]. Kegiatan belajar di Taman Kanak-Kanak dirancang untuk membentuk perilaku dan mengembangkan kemampuan dasar yang ada dalam diri anak usia Taman Kanak-Kanak, dalam pelaksanaan pembelajaran sains harus disesuaikan dengan tahap-tahap perkembangan anak.

Pengembangan pembelajaran sains pada anak, termasuk bidang pengembangan lainnya memiliki peranan yang sangat penting dalam membantu perkembangan kognitif pada anak usia dini. Kesadaran pentingnya pembekalan sains pada anak akan semakin tinggi apabila menyadari bahwa kita hidup pada dunia yang dinamis, berkembang dan berubah secara terus-menerus bahkan semakin menuju masa dewasa, semakin kompleks ruang lingkupnya, dan tentunya akan semakin memerlukan sains[9]. Pendidikan sains menekankan pada pemberian pengalaman secara langsung. Dengan demikian, anak perlu dibantu untuk mengembangkan sejumlah keterampilan proses sains agar mampu menjelajahi serta memahami alam sekitarnya. Sains sebagai suatu ilmu pengetahuan tentang alam sekitar yang merupakan proses yang berisikan teori atau konsep yang diperoleh melalui pengamatan dan penelitian. Sains sebagai suatu deretan konsep yang berhubungan satu sama lain yang didasarkan atas hasil pengamatan, percobaan-percobaan atas gejala alam dan isi alam semesta.

Dalam pelaksanaan proses belajar mengajar sains di Taman Kanak-Kanak, guru harus memahami dan menguasai metode pembelajaran sains yang digunakan. Dengan menguasai metode pembelajaran sains, diharapkan tujuan pendidikan di Taman KanakKanak yaitu untuk mengembangkan kemampuan fisik, kognitif, bahasa, sosialemosional, konsep diri, disiplin, kemandirian, seni, moral, dan nilai-nilai agama dapat tercapai secara terpadu dan optimal. Peningkatan lembaga PAUD ini juga harus memperhatikan kualitas sehingga tumbuh kembang anak bisa lebih ditingkatkan. Selain itu, kualitas pendidik PAUD juga harus diperhatikan sehingga metode pembelajaran berfokus pada keaktifan anak dalam proses pembelajaran. Keterbatasan sarana dan prasarana PAUD serta ketersediaan dan penggunaan bahan ajar dan media pembelajaran kadang masih menjadi masalah[10]. Untuk menunjang terjadinya proses tersebut, guru harus menyiapkan metode yang tepat dalam pembelajaran. Anak usia dini 
membutuhkan metode yang dapat membuat mereka berinteraks langsung dengan kejadian yang dilakukan.

Salah satu metode yang dapat diterapkan dalam pembelajaran sains yaitu metode eksperimen. Metode ini memberikan kesempatan pada anak untuk lebih bereksplorasi dalam kegiatan pembelajaran. Metode eksperimen adalah cara penyajian pelajaran, dimana siswa melakukan percobaan dengan mengalami dan membuktikan sendiri sesuatu yang dipelajari. Metode eksperimen adalah percobaan tentang sesuatu. Dalam hal ini setiap anak bekerja sendiri-sendiri. Pelaksanaan lebih memperjelas hasil belajar, karena setiap anak mengalami dan melakukan kegiatan percobaan. Dengan menggunakan metode ini anak dapat menemukan sesuatu hal yang baru dengan pengalamannya sendiri. Metode eksperimen merupakan cara yang digunakan untuk menyajikan pembelajaran, dimana anak melakukan percobaan dengan mengalami dan membuktikan sendiri sesuatu yang dipelajari. Selaras dengan hal diatas Abimanyu mengungkap bahwa metode eksperimen adalah cara penyajian pelajaran yang memungkinkan anak melakukan percobaan sendiri untuk membuktikan suatu pertanyaan atau hipotesis yang dipelajari[11].

Metode yang digunakan untuk mengembangkan kognitif anak yaitu metode yang mampu menggerakan anak agar dapat berpikir, menalar, mampu menarik kesimpulan, dan membuat generalisasi. Caranya adalah dengan memahami lingkungan disekitarnya, mengenal orang dan benda-benda yang ada, memahami tubuh dan perasaan mereka sendiri, melatih memahami untuk mengurus diri sendiri. Selain itu melatih anak untuk menggunakan bahasa untuk berhubungan dengan orang lain, dan melakukan apa yang dianggap benarberdasarkan nilai yang ada dalam masyarakat. Metode yang dipilih untuk meningkatkan sains anak adalah metode yang dapat menggerakan anak untuk meningkatkan motivasi, rasa ingin tahu, dan mengembangkan imajinasi. Dalam mengembangkan sains anak, metode yang dipergunakan mampu mendorong anak mencari dan menemukan jawabannya., membuat pertanyaan yang membantu memecahkan, memikirkan kembali, membangun kembali, dan menemukan hubunganhubungan baru[12].

Salah satu metode pembelajaran sains yang digunakan di Raudhatul Athfal Nurul Hidayah, Desa Harumandala Kecamatan Cigugur, Kabupaten Pangandaran ini yaitu metode eksperimen. Namun karena metode eksperimen perlu persiapan yang matang untuk melaksanakanannya dari mulai mempersiapkan alat dan bahan yang dibutuhkan dan kesiapan guru dalam mendemonstrasikan kegiatan yang akan dilaksanakan sehingga metode ini jarang dilaksanakan, padahal penggunaan metode eksperimen pada pembelajaran sains dapat memudahkan anak dalam memahami konsep sains sederhana, dimana siswa melakukan percobaan dengan mengalami dan membuktikan sendiri sesuatu yang dipelajari. Permasalahan lain yang dihadapi di RA Nurul Hidayah adalah peserta didik mengalami kesulitan dalam memahami konsep sains sederhana, sebagian besar anak tidak tertarik untuk mengikuti pembelajaran sains dikarenakan media dan metode pembelajaran yang kurang menarik dan kegiatan yang dilakukan cenderung menekankan pada hasil bukan aktivitas atau proses.

\section{METODE}

Metode yang digunakan pada penelitian ini adalah menggunakan metode penelitian kualitatif. Penelitian ini menggunakan pendekatan kualitatif deskriptif, yaitu penelitian yang berusaha mendeskripsikan suatu gejala, peristiwa, kejadian yang terjadi pada saat sekarang[13]. Informan pada penelitian ini adalah anak usia dini yang 
berjumlah 16 peserta didik pada RA Nurul Hidayah Harumandala. Pada jenis penelitian deskriptif, data yang dikumpulkan berupa kata-kata, gambar dan bahkan angka-angka. Teknik pengumpulan data yang digunakan antara lain teknik observasi, wawancara, dan teknik dokumentasi Dengan demikian, laporan penelitian akan diberi kutipan-kutipan data untuk memberikan gambaran penyajian laporan tersebut. Data tersebut berasal dari naskah wawancara, catatan lapangan, catatan atau memo dan dokumen resmi misalnya[14]. Sehingga penelitian ini tujuannya untuk mendeskripsikan tentang kegiatan penggunaan metode eksperimen pada pembelajaran sains bagi anak usia dini di RA Nurul Hidayah Harumandala. Selain itu, peneliti melakukan penelitian dengan menguraikan fakta-fakta yang terjadi secara alamiah dengan menggambarkannya secara semua kegiatan yang dilakukan melalui pendekatan lapangan, dimana usaha pengumpulan data dan informasi secara intensif disertai analisa dan pengujian kembali atas semua yang telah dikumpulkan.

\section{HASIL DAN PEMBAHASAN}

Hasil observasi yang dilakukan pada tanggal 19 Agustus 2020, peneliti mengadakan penelitian terkait pembelajaran sains di RA Nurul Hidayah Harumandala untuk mengetahui kondisi awal perkembangan pembelajaran sains di kelas B RA Nurul Hidayah Harumandala yang berjumlah 16 anak. Berdasarkan hasil pengamatan, peneliti menyimpulkan bahwa kemampuan anak dalam pembelajaran sains sangat kurang. Hal ini terlihat saat pembelajaran sains mengenal warna dimana anak diminta untuk menyebutkan warna yang mereka lihat di sekitarnya tanpa penjelasan terlebih dahulu. Adapun hasil pengamatannya hampir sebagian besar kemampuan anak didik sebagian besar belum mengenal warna. Langkah-langkah pelaksanaan penggunaan metode eksperimen pada pembelajaran sains di RA Nurul Hidayah Desa Harumandala: 1. Guru Melakukan Persiapan Penggunaan Metode Eksperimen Pembelajaran Sains, 2. Guru Mempersiapkan Kegiatan Pembelajaran Sains Yang Akan dilakukan, 3. Guru Memilih Untuk Melakukan Kegiatan Pembelajaran Sains Dengan Menggunakan Metode Eksperimen, 4. Guru Memberikan Penjelasan Kepada Anak Didik Terkait Kegiatan Yang Akan dilakukan Pada Pembelajaran Sains, 5. Guru memberikan kesempatan kepada anak untuk mempraktekan langsung bereksperimen, 6. Guru memberikan pujian kepada anak ketika anak berhasil bereksperimen, 7. Guru mengawasi anak ketika kegiatan bereksperimen dan 8. Guru berdiskusi dengan anak untuk menarik kesimpulan dari percobaan yang telah mereka lakukan.

Ada beberapa cara yang dilakukan oleh guru dalam persiapan pembelajaran metode eksperimen pada pembelajaran sains diantaranya menyiapkan Rencana Pelaksanaan Pembelajaran Harian (RPPH), metode pembelajaran, media pembelajaran serta bahan dan alat pembelajaran sains. Hal ini sesuai yang diungkapkan oleh Ibu IS selaku guru kelas B RA Nurul Hidayah, bahwa: Sebagai seorang pendidik sebelum memulai pembelajaran terlebih dahulu saya menyiapkan Rencana Pelaksanaan Pembelajaran Harian (RPPH), memilih metode pembelajaran, menyiapkan media pembelajaran yang sesuai dengan tema yang ada pada Rencana Pelaksanaan Pembelajaran Mingguan (RPPM). Sebelum memulai pembelajaran sains dengan menggunakan metode eksperimen terlebih dahulu guru menyiapkan tema yang sesuai dengan pembelajaran sains kemudian guru mempersiapkan alat dan bahan yang dibutuhkan untuk kegiatan tersebut (IS, Guru Kelas B, Wawancara. Pada tanggal 22 Agustus 2020). Berdasarkan pernyataan diatas maka di RA Nurul Hidayah Harumandala 
selalu menyiapkan RPPH, RPPM, metode pembelajaran, tema, alat dan bahan terlebih dahulu sebelum melaksanakan kegiatan pembelajaran sains.

Selain menyiapkan alat dan bahan pembelajaran, Seorang guru harus mempersiapkan percobaan atau eksperimen apa yang akan dilaksanakan pada pembelajaran sains, contohnya eksperimen mencampur warna, sesuai dengan tema pembelajaran agar kegiatan pembelajaran berlangsung dengan baik. Seperti yang diungkapkan oleh kepala sekolah RA Nurul Hidayah, bahwa: Sebelum melaksanakan kegiatan eksperimen pada pembelajaran sains biasanya kami menentukan terlebih dahulu percobaan yang akan dilakukan dalam pembelajaran sains sesuai tema pembelajaran pada hari ini. Kami akan melakukan eksperimen mencampur warna supaya anak mudah memahami konsep warna (Kepala Sekolah, Wawancara. Pada tanggal 22 Agustus 2020).

Guru berperan penting dalam penggunaan metode eksperimen pada pembelajaran sains bagi anak usia dini melalui metode eksperimen dan didukung dengan media pembelajaran serta alat dan bahan pembelajaran maka anak lebih mudah untuk mengikuti proses pembelajaran. Dalam hal ini guru dijadikan pigur oleh anakanak karena apa yang dikatakan dan dilakukan oleh guru akan diikuti dan dipatuhi oleh anak. Ada beberapa tahapan yang dilakukan oleh guru dalam penggunaan metode eksperimen yaitu: Memilih strategi yang cocok untuk penggunaan metode eksperimen pada pembelajaran sains dan Menggunakan metode eksperimen pada pembelajaran sains Sesuai dengan pernyataan dari Ibu AA selaku guru pendamping kelas B bahwa: untuk melakukan kegiatan pembelajaran sains contohnya mencampur warna, kami biasanya menyiapkan metode yang dapat secara langsung anak bereksplorasi yaitu metode eksperimen supaya anak antusias untuk mengikuti pembelajaran dan supaya anak mudah paham dengan apa yang disampaikan (AA, Guru Pendamping Kelas B, Wawancara. Pada tanggal 24 Agustus 2020).

Sebelum melakukan percobaan guru membagi anak menjadi beberapa kelompok dan memberikan penjelasan tentang kegiatan yang akan dilakukan, guru mengenalkan alat dan bahan yang digunakan, selanjutnya guru memberikan arahan terkait langkahlangkah percobaan yang akan dilakukan. Selaras dengan pernyataan Ibu IS selaku guru kelas B bahwa: Sebelum melakukan kegiatan mencampur warna, kami megenalkan alat dan bahan yang akan digunakan yaitu pewarna makanan berwarna primer yaitu warna kuning, biru dan merah, gelas pelastik dan air. Kemudian kami memberikan contoh proses mencampurkan warna dari mulai mengisi gelas dengan air sebanyak 3 gelas, kemudian masing-masing gelas berisi air tersebut diberi pewarna kuning, merah, dan biru. Setelah itu, guru mencoba mencampurkan warna kuning kedalam gelas berwarna merah, warna biru kedalam gelas berwarna merah dan warna kuning kedalam gelas berwarna biru.Kemudian anak-anak melihat secara langsung reaksi yang terjadi dari masing-masing gelas tersebut (IS, Guru Kelas B, Wawancara. Pada tanggal 24 Agustus 2020).

Setelah guru memberikan penjelasan dan memberikan contoh terkait kegiatan yang akan dilakukan, kemudian guru memberikan kesempatan kepada anak untuk melakukan langsung kegiatan bereksperimen. Kepala sekolah menyatakan bahwa: Kami memberi kesempatan langsung kepada anak memperaktekan kegiatan yang sudah dijelaskan sebelumnya, kami mengambil tema Air,Udara dan Api. kami bereksperimen mencampur warna. Anak-anak langsung memperaktekan sesuai dengan apa yang sudah dijelasakan oleh guru. Kami senang mereka sangat suka dengan eksperimen tersebut (Kepala Sekolah, Wawancara. Pada tanggal 24 Agustus 2020). Mempraktekkan langsung memberikan pengalaman baru bagi anak. Karena pada dasarnya anak akan suka dengan 
hal-hal baru yang dialami. Selain itu dengan mempraktekkan langsung, kemampuan motorik anak akan terlatih.

Pujian memiliki efek yang kuat pada anak-anak yang sedang berkembang.Pujian dapat memupuk harga diri dan kepercayaan diri mereka untuk terus berusaha keras. Anak akan termotivasi untuk menemukan strategi untuk mengatasi tantangan. Contohnya guru memberikan pujian karena anak mampu melakukan kegiatan mencampur warna tanpa bantuan dari orang lain, dan anak mampu menyebutkan warna yang dihasilkan dari eksperimen mencampur warna.

Selain memberikan penjelasan dan memberikan contoh terkait kegiatan yang akan dilakukan, guru juga bertugas mengawasi kegiatan yang sedang dilakukan oleh anak supaya tidak terjadi hal-hal yang tidak diinginkan. Setelah kegiatan selesai selanjutnya guru berdiskusi atau bercakap-cakap tentang kegiatan yang telah dilakukan, guru melakukan kegiatan Tanya jawab terkait kegiatan tersebut.

Berdasarkan hasil penelitian yang peneliti lakukan di Raudhatul Athfal (RA) Nurul Hidayah Harumandala, bahwa indikator pencapaian yang peneliti dapatkan ketika menggunakan metode eksperimen pada pembelajaran sains mencampur warna adalah sebagai berikut: (a) Anak mampu mengamati alat dan bahan; (b) Anak dapat memprediksi warna yang akan dihasilkan dari pencampuran; (c) Anak dapat mencampurkan warna sendiri; (d) Anak mengamati reaksi dari pencampuran warna; (e) Anak dapat mengelompokkan warna primer; (f) Anak dapat mengelompokkan warna sekunder; (g) Anak mampu menggunakan alat dan pengukuran air; (h) Anak menceritakan hasil dari pencampuran warna. Hasil penerapan pembelajaran eksperimen ini bisa meningkatkan pengetahuan anak usia dini dalam pengenalan sains. Hal ini di ungkapkan oleh Khaeriyah dalam hasi penelitiannya bahwa penerapan metode eksperimen dalam pembelajaran sains untuk meningkatkan kemampuan kognitif anak usia dini di RA Baiturrahman memperoleh hasil yang baik. Pada awal penelitian, kemampuan kognitif dalam pembelajaran sains anak masih rendah. Hasil pra siklus menunjukan $44.38 \%$ artinya masih belum mampu. Kondisi ini berakibat pada terganggunya kemampuan dan pembelajaran sains anak seperti anak masih belum mengetahui tentang pencampuran wana, anak yang belum mampu mengenal benda dengan mengurutkan benda berdasarkan ukuran dari yang terpendek sampai yang terpanjang atau sebaliknya, dan anak jugabelum mampu mengungkapkan hasil karya yang dibuatnya secara lengkap[15].

Dalam penerapan metode eksperimen tentulah ada faktor-faktor yang menjadi penghambat dan faktor pendukung dalam peneraparan Penggunaan Metode Eksperimen. Faktor pendukung penggunaan metode eksperimen pada pembelajaran sains, berdasarkan hasil penelitian yang peneliti lakukan selama kegiatan penelitian berlangsung, berdasarkan hasil wawancara yang dipaparkan oleh Ibu Kepala Sekolah bahwa diantara faktor pendukung penggunaan metode eksperimen pada pembelajaran sains bagi anak usia dini ialah sebagai berikut: Guru memahami sepenuhnya mengenai eksperimen itu sendiri dan mengetahui cara yang tepat untuk menerapkannya pada anak, Guru memberikan pengawasan serta instruksi yang tepatsehingga pengalaman yang didapatkan anak sesuai dengan yang diharapkan. Sarana dan prasarana yang digunakan memadai dan Situasi lingkungan yang mendukung untuk untuk melakukan eksperimen tersebut (Kepala Sekolah, Wawancara. Pada tanggal 24 Agustus 2020).

Faktor penghambat penggunaan metode eksperimen pada pembelajaran sains, berdasarkan hasil wawancara yang peneliti dapatkan pada bulan Agustus lalu, menurut kepala sekolah di RA Nurul Hidayah Harumandala, beliau mengatakan bahwa faktor penghambat penggunaan metode eksperimen pada pembelajaran sains adalah sebagai 
berikut: Terdapat dua orang anak yang masih diantar oleh orangtuanya ke dalam kelas yang menyebabkan anak hilang konsentrasi, Penelitian yang dilakukan kurang maksimal karena ada dalam masa pandemi covid 19, Kegiatan cenderung tergesa-gesa karena waktu tatap muka dibatasi, Sedikitnya waktu yang dimiliki guru dalam mengajar, Sulit mencari alat dan bahan untuk melakukan eksperimen, Masih terdapat beberapa eksperimen yang tidak dapat dilakukan dikarenakan tidak ada alat dan bahan yang disediakan oleh sekolah dan Biaya, dikarenakan dalam menggunakan metode ini memerlukan alat dan bahan yang tidak sedikit (Kepala Sekolah, Wawancara. Pada tanggal 24 Agustus 2020). Berdasarkan hasil penelitian Winarni menyimpulkan bahwa kesulitan guru dalam membelajarakan sains adalah pemahaman konsep sains yang masih kaku mengikuti buku acuan, keterbatasan alat, bahan, dan waktu, serta penerapan konsep sains yang belum mengacu pada lingkungan anak usia dini. Adanya perbedaan kondisi suatu daerah menyebabkan guru tidak mampu mengaplikasikan konsep sains, guru mengajarkan sains pada anak usia dini seperti mengajarkan sains pada anak sekolah dasar. Oleh karena itu kompetensi guru harus ditingkatkan sesuai dengan tujuan membelajarkan sains pada anak usia dini. Pembelajaran sains tidak harus terlihat ilmiah sekali, tetapi cukup dengan mengkaitkan pada kegiatan anak sehari-hari akan lebih mudah dipahami oleh logika dan imajenasi anak usia dini. Dengan begitu konsep sains sudah tertanam dan menjadi pemicu bagi anak untuk lebih bereksplorasi terhadap lingkungan di sekitarnya[16].

Berdasarkan hasil pelaksanaan kegiatan eksperimen pada pembelajaran sains yang dilakukan pada anak didik kelas B RA Nurul Hidayah dapat peneliti jelaskan bahwa selama pelaksanaan anak didik antusias dan aktif dalam melakukan percobaan. Hasil observasi juga didukung oleh wawancara dengan Ibu IS selaku guru kelas B RA Nurul Hidayah Harumandala tentang cara guru dalam menggunakan metode eksperimen pada pembelajaran sains di RA Nurul Hidayah Harumandala adalah sebagai berikut: Sebelum masuk kegiatan inti terlebih dahulu anak melakukan baris berbaris dengan bernyanyi bersama, anak membacakan doa-doa pendek bersama setelah itu masuklah pada kegiatan inti dimana kegiatan pembelajaran sains dengan kegiatan mencampur warna. Sebelum melakukan kegiatan mencampur warna guru terlebih dahulu menyiapkan alat, bahan dan pewarna yang tidak membahayakan anak. Kemudian guru menjelaskan dan memperaktekan bagaimana tata cara mencampurkan warna sehingga menjadi warna baru seperti warna merah dicampur dengan warna kuning akan menghasilkan warna jingga dan warna merah dicampur dengan warna biru akan menghasilkan warna ungu sedangkan warna biru dicampur warna kuning akan menghasilkan warna hijau, ini dikarenakan campuran dua warna atau lebih akan menghasilkan warna baru (IS, Guru Kelas B, Wawancara. Pada tanggal 24 Agustus 2020).

Selaras dengan pernyataan diatas, Ibu AA selaku guru pendamping kelas B RA Nurul Hidayah Harumandala menyatakan: Anak tampak berperan aktif pada saat kegiatan pembelajaran pencampuran warna berlangsung.Anak begitu antusias bereksperimen dalam mencampurkan warna agar tercipta warna yang baru.Sesekali guru membantu anak dalam pelaksanaan kegiatan pembelajaran tersebut agar tidak terjadi yang tidak diinginkan seperti cat warna tertumpah, berserakan dan mengenai baju anak (AA, Guru Pendamping Kelas B, Wawancara. Pada tanggal 26 Agustus 2020). Kepala sekolah RA Nurul Hidayah Harumandala juga menyatakan: Saya mendukung kegiatan eksperimen mencampurkan warna yang dilakukan oleh guru dengan menyediakan media, sarana dan prasarana serta alat dan bahan yang dibutuhkan dalam kegiatan tersebut karena saya merasa bahwa kegiatan sederhana ini dapat mengembangkan aspek perkembangan anak. Dan saya yakin bahwa dalam kegiatan ini 
anak sangat senang dalam mengikuti proses kegiatannya dikarenakan anak menyukai bermacam-macam warna (Kepala Sekolah, Wawancara. Pada tanggal 26 Agustus 2020). Wawancara dengan Ibu IS selaku guru kelas B RA Nurul Hidayah Harumandala menyatakan: Pada saat kegiatan sedang berlangsung disini guru mengawasi anak ketika melakukan kegiatan mencampur warna dan guru dapat melihat anak telah melakukan kegiatan mencampur warna dengan baik karena anak sudah bisa melakukan pencampuran warna dengan warna lain dan menghasilkan warna baru. Kemudian guru memerintahkan agar membersihkan alat-alat yang yang digunakan anak dalam kegiatan tersebut.Kegiatan mencampur warna ditutup dengan bernyanyi dan berdoa bersama (IS, Guru kelas B, Wawancara. Pada tanggal 24 Agustus 2020).

Dari hasil observasi diatas, maka peneliti dapat mengambil kesimpulan bahwa kegiatan pencampuran warna bertujuan untuk mengembangkan beberapa aspek perkembangan anak diantaranya aspek kognitif anak dimana anak dapat memecahkan suatu masalah, aspek motorik dimana anak dapat melakukan pencampuran warna dengan warna yang lain dan menghasilkan warna yang baru. Kegiatan ini juga disukai anak-anak dikarenakan warna-warna yang cerah seperti warna merah dicampur dengan warna kuning akan menghasilkan warna jingga dan warna merah dicampur dengan warna biru akan menghasilkan warna ungu sedangkan warna biru dicampur dengan warna kuning akan menghasilkan warna hijau sehingga anak tidak merasa mudah bosan ketika pembelajaran sedang berlangsung. Hasil penelitian Marselina menyimpulkan bahwa Penerapan metode eksperimen dalam pembelajaran sains untuk meningkatkan kemampuan kognitif anak usia dini di Santa Yohana Antida 2 Sintang memperoleh hasil yang baik. Pada awal penelitian, kemampuan kognitif dalam pembelajaran sains anak masih rendah. Hasil pra siklus menunjukan $63,3 \%$ artinya masih belum mampu. Kondisi ini berakibat pada terganggunya kemampuan dan pembelajaran sains anak seperti anak masih belum mengetahui tentang pencampuran wana, anak yang belum mampu mengenal benda dengan mengurutkan benda berdasarkan ukuran dari yang terpendek sampai yang terpanjang atau sebaliknya, dan anak jugabelum mampu mengungkapkan hasil karya yang dibuatnya secara lengkap[17].

Pada pembelajaran sains, disini anak yang berperan aktif dalam kegiatan pencampuran warna, anak melakukan pencampuran warna dengan sendiri tanpa bantuan dari guru anak hanya mengikuti instruksi yang diberikan oleh guru, warna apa yang harus dicampurkan dengan warna lain sehingga dapat menghasilkan warna baru. Anak menggunakan warna primer seperti warna merah, kuning dan biru seperti warna merah dicampur dengan warna biru akan menghasilkan warna ungu, warna merah dicampur dengan warna kuning akan menghasilkan warna jingga sedangkan warna biru dicampur dengan warna kuning akan menghasilkan warna hijau. Pada saat pelaksanaan penelitian berlangsung peneliti melakukan observasi atau pengamatan dengan mengisi instrument yang sudah disiapkan, yaitu lembar observasi terhadap kesiapan anak didik pada saat kegiatan berlangsung dan menilai peningkatan kemampuan sains (mengenal warna). Berikut hasil pengamatan anak didik dalam meningkatkan kemampuan sains melalui metode eksperimen. Adapun aspek-aspek yang diamati adalah sebagai berikut: Anak mengamati alat dan bahan, Anak dapat memprediksi warna yang akan dihasilkan dari pencampuran, Anak dapat mencampurkan warna sendiri, Anak mengamati reaksi dari pencampuran warna, Anak dapat mengelompokkan warna primer, Anak dapat mengelompokkan warna sekunder, Anak mampu menggunakan alat dan pengukuran air dan Anak dapat menceritakan hasil dari pencampuran warna.

Berdasarkan analisis data dapat diketahui bahwa dari hasil pengamatan pada sebelum melakukan pembelajaran sains dengan metode eksperimen, anak yang 
termasuk kategori Berkembang Sangat Baik (BSB) tidak ada, Berkembang Sesuai Harapan (BSH) sebanyak 5 anak, kategori Mulai Berkembang sebanyak 8 anak dan kategori Belum Berkembang sebanyak 3 anak. Setelah menggunakan metode eksperimen pada pembelajaran sains, jumlah anak yang berkembang sangat baik (BSB) sebanyak 7 anak, sedangkan anak yang berkembang sesuai harapan (BSH) sebanyak 4 anak, dalam kategori mulai berkembang (MB) sebanyak 5 anak, dalam kategori belum berkembang (BB) tidak ada. Hasil pengamatan menunjukan bahwa Analisis penggunaan metode eksperimen pada pembelajaran sains pada anak melalui pengenalan warna sudah berhasil, keberhasilan tersebut dapat dilihat dari bertambahnya jumlah anak yang berkembang sangat baik dari setiap pertemuan. Maka penggunakan metode eksperimen pembelajaran sains pada kelompok B di PAUD Nurul Hidayah dinyatakan berhasil. Hasil penelitian yang lain memperlihat penerapan metode eksperimen ini baik dalam pembelajaran sain. Berdasarkan hasil penelitian yang dilakukan oleh Martati pada kelompok B RA Wildaanun Rabbaniyyun Kendari selama dua siklus, maka dapat disimpulkan bahwa kreativitas anak dapat ditingkatkan melalui metode eksperimen. Hal ini dapat dilihat pada nilai observasi awal sebesar 33,3\%, pada nilai klasikal anak siklus I meningkat yaitu 60\%, dan pada siklus II lebih meningkat lagi menjadi $86,67 \%$, berdasarkan hasil observasi guru pada siklus 1 memperoleh presentase sebesar $64 \%$ dan pada siklus II meningkat menjadi 93\%, sedangkan hasil observasi aktivitas anak pada pelaksanaan siklus I, memperoleh presentase sebesar $57 \%$ dan pada siklus II meningkat menjadi 86\%[18].

Berdasarkan hasil penelitian yang telah dilaksanakan maka dapat ditarik kesimpulan bahwa penggunakan metode eksperimen pada pembelajaran sains bagi anak usia dini terutama dalam hal mengenal warna di PAUD Nurul Hidayah Harumandala mengalami peningkatan. Peningkatan ini ditunjukan melalui kemampuan sains peserta didik yang telah diamati dalam pelaksanaan kegiatan pembelajaran. Maka dari itu dapat ditarik kesimpulan bahwa melalui penggunaan metode eksperimen pada pembelajaran sains dapat meningkatkan kemampuan anak dalam memahami konsep sains sederhana dan meningkatkan motivasi anak terhadap pembelajaran sains di RA Nurul Hidayah Harumandala dan hasilnya sebagian besar anak dalam kategori berkembang sangat baik.

\section{KESIMPULAN}

Berdasarkan hasil penelitian yang dilakukan dapat disimpulkan bahwa pada tahapan pelaksanaan penggunaan metode eksperimen pada pembelajaran sains bagi anak usia dini di PAUD RA Nurul Hidayah Desa Harumandala, melalui dukungan media pembelajaran serta alat dan bahan pembelajaran maka anak akan lebih mudah untuk mengikuti proses pembelajaran. Dalam hal ini guru dijadikan figur oleh anak-anak karena apa yang dikatakan dan dilakukan oleh guru akan diikuti dan dipatuhi oleh anak. Dengan menggunakan metode eksperimen pada pembelajaran sains bagi anak usia dini di RA Nurul Hidayah Harumandala peserta didik dapat mengikuti proses tersebut dengan baik, dan ketika anak diminta oleh guru untuk melakukan eksperimen tersebut anak menanggapinya dengan antusias dan penuh semangat. Sebagian besar anak-anak dalam melakukan eksperimen sudah berhasil dengan baik, dan masih terdapat beberapa anak juga yang kurang sabar dalam melakukan eksperimen dan ketika anak diminta oleh guru untuk menceritakan hasil eksperimennya mereka dapat menceritakannya sesuai dengan apa yang mereka lihat ketika guru memberi contoh dan ketika anak melakukan percobaan sendiri. Jadi dapat peneliti katakana bahwa dengan menggunakan 
metode eksperimen pada pembelajaran sains bagi anak usia dini di PAUD RA Nurul Hidayah Harumandala perkembangan anak dalam memahami konsep sains sederhana sebagian besar anak dalam kategori berkembang sangat baik.

\section{PENGHARGAAN}

Terima kasih penulis ucapkan kepada kepala sekolah dan para guru yang di di RA Nurul Hidayah Harumandala yang telah meluangkan waktunya untuk mengisi instrument penelitian ini dan semua pihak yang telah membantu pelaksanaan penelitian dan penulisan artikel ini. Tidak lupa ucapan terima kasih kepada editor dan reviewer Jurnal Murhum yang sudah memberikan kesempatan sehingga jurnal bisa untuk diterbitkan

\section{REFERENSI}

[1] L. Mukhtar and others, "Orientasi Baru Pendidikan Anak Usia Dini," Jakarta Kencana Prenada Media Gr., 2013.

[2] L. Anhusadar, "Assessment Dalam Pendidikan Anak Usia Dini," Al-Ta'dib, vol. 6, no. 1, pp. 58-70, 2013.

[3] H. E. Mulyasa, "Manajemen Paud," Bandung: Remaja Rosdakarya, 2012.

[4] S. Suriati, S. Kuraedah, E. Erdiyanti, and L. O. Anhusadar, "Meningkatkan Keterampilan Motorik Halus Anak melalui Mencetak dengan Pelepah Pisang," J. Obs. J. Pendidik. Anak Usia Dini, vol. 4, no. 1, p. 211, 2019.

[5] D. Mutiah, Psikologi bermain anak usia dini. Kencana, 2015.

[6] F. Muhammad, “Desain Pembelajaran PAUD," Jakarta: Ar-Ruz Media, 2012.

[7] Hasnida, Media Pembelajaran Kreatif,. Jakarta: PT. Luxima Metro Media, 2014.

[8] Y. N. Sujiono, "Konsep dasar pendidikan anak usia dini," 2009.

[9] B. Mursid, "Pengembangan pembelajaran PAUD," Bandung PT Remaja Rosdakarya, 2015.

[10] L. Anhusadar, "Evaluasi Pelaksanaan Standar Produk Hasil Belajar pada Satuan Pendidikan Anak Usia Dini," Al-TA'DIB J. Kaji. Ilmu Kependidikan, vol. 13, no. 1, p. 34, Jun. 2020.

[11] I. G. A. S. P. Dewi, I. K. Gading, and M. Magta, "Penerapan Metode Eksperimen Untuk Meningkatkan Kemampuan Kognitif Anak Usia 4--5 Tahun TK Saiwa Dharma Banyuning Singaraja," J. Pendidik. Anak Usia Dini Undiksha, vol. 4, no. 3, 2016.

[12] M. M. Roza, "Pelaksanaan Pembelajaran Sains Anak Taman Kanak-Kanak Aisyiyah Bustanul Athfal 29 Padang," J. Ilm. Pesona PAUD, vol. 1, no. 5, 2012.

[13] M. D. Ghony, "Penelitian Tindakan Kelas.” UIN-Maliki Press, 2008.

[14] B. Burhan, "Analisis Data Penelitian Kualitatif: Pemahaman Filosofis dan Metodologis ke Arah Penguasaan Model Aplikasi," Jakarta PT Raja Graf. Persada, 2003.

[15] E. Khaeriyah, A. Saripudin, and R. Kartiyawati, "PENERAPAN METODE EKSPERIMEN DALAM PEMBELAJARAN SAINS UNTUK MENINGKATKAN KEMAMPUAN KOGNITIF ANAK USIA DINI," AWLADY J. Pendidik. Anak, vol. 4, no. 2, p. 102, Sep. 2018.

[16] D. S. Winarni, "Analisis Kesulitan Guru PAUD dalam Membelajarakan IPA pada Anak Usia Dini," Edu Sains J. Pendidik. Sains Mat., vol. 5, no. 1, p. 12, Aug. 2017.

[17] T. Yayuk Marselina STKIP Persada Khatulistiwa Sintang and J. Sengkuang Km, 
"Metode Eksperimen Dalam Pembelajaran Sains Untuk Meningkatkan Kemampuan Kognitif Anak Usia Dini Di Tk Santa Yohana Antida 2 Sintang," J. Pendidik. Anak Usia Dini, vol. 1, no. 1, 2019.

[18] M. G. Elis Martati, "Meningkatkan Kreativitas Anak Melalui Metode Eksperimen," J. Ris. Golden Age PAUD UHO, vol. 1, no. 3, 2018. 